\title{
The Electronic Customer-To-Customer Interaction Based on Real Estate Consumption
}

\author{
Jing XUE \\ College of Economy and Management, Yunnan Open University, Kunming 650223, P.R. China
}

\begin{abstract}
At present, the relevant studies mostly focus on the CCI of service industry in reality, while pay less attention to the $\mathrm{CCI}$ of the production and service industries in virtual environment. Basing on the China's real estate industry, this study explored the components of electronic CCI (ECCI). Moreover, with the assistance of references and in-depth interview, it established the measurement scale of ECCI in real estate consumption. Finally, the scale was proved through empirical test.
\end{abstract}

KEYWORD: Electronic customer-to-customer interaction; real estate consumption; virtual environment; empirical study

\section{INTRODUCTION}

In recent thirty years, theoretical researchers have explored the relationship between enterprises and customers and discussed the way for improving customer satisfaction and establishing customer loyalty by building favorable relationships. Martin (1996) identified five important links for establishing the relationship between enterprises and customers. One of the most important ways is the link among customers. Many subsequent researchers investigated the issues related to interactions among customers and achieved great progress. However, the study on the CCI in pure real environment has been incapable of satisfying reality demands. Therefore, many researchers now focus to electronic customerto-customer interaction (ECCI). Libai et al (2010) found that, the main reason for the interest increase of researchers on the CCI in the marketing field lies in the fundamental transformation of the linking way among customers through social media. Nieholls (2008) recommended to explore the ECCI and treated the ECCI as the challenge for study the CCI in future.

Jiang (2012) found that CCI is industrydependent. Previous relevant researches are mostly related to the service industry while neglect real estate industry. Currently, China has a large number of real estate industry enterprises. Since these enterprises mostly focus on short-term profits, the estate consumer satisfaction survey showed unsatisfactory survey results. However, In previous statistics, patrons' recommendation accounts for a high proportion in regard of cable source and transaction probability. Therefore, it is urgent for real estate enterprises in China to transform the management form, that is, focus on trade mode to relationship mode, to explore the psychological needs of consumers and consumer behavior characteristics. Theoretical researchers have thoroughly investigated the satisfaction degree of real estate industry. Unfortunately, these researches started from the link between enterprise and customer and failed to consider the role of CCI link.

\section{LITERATURE REVIEW}

Clark \& Martin (1994) and Nicholls (2010) pointed out that CCI was a forgotten marketing relationship. Subsequently, some studies explored the cause and effect of CCI, while others focus on the influences of CCI behavior on social role and social behavior. For example, Baron \& Harris (2007) found that CCI behavior leaded to the image and reputation growth of individual in society. In addition, they paid attention to the positive or negative influences of $\mathrm{CCI}$ behavior on the marketing results.

ECCI refers to the CCI in electronic form. CCI emphasizes on the behaviors among customers occasionally happening in the real in-situ or ex-situ environment, while ECCI is likely to have clear goals and is generated by new social forms, such as micro message, micro-blog, virtual community, and forum, etc. Some researches paid attention to the customer behaviors in virtual brand community. For 
example, Muniz \& O'Guinn (2001) pointed out that virtual brand community was a consumption group accumulated through network due to the interest on identical brand or product. Dominik Georgi \& Moritz Mink (2013) believed that virtual brand community was involved in ECCI. Owning to inclusion relationship, the range of ECCI should be expanded from the service consumption to product consumption.

Previous CCI researches mainly concentrate on typical service industry. However, the range of ECCI behavior should be expanded to product and service consumption field and involve the CCI behaviors asynchronously occurring with trade or anonymously occurring ones. The generation is through electricity. The studies concerning the product service field are mainly based on retail industry. They discuss the CCI behaviors in the environment and have not investigated the loaded ECCI behavior.

\section{EXPLORATION OF LOADED ECCI}

\subsection{Process of exploratory study}

According to the experience of previous research, this study used the key event technology proposed by Flanagan for exploratory research. Data were collected by questionnaires with open question. The basic content of the questionnaires was to ask the residential commercial housing consumers to recall a satisfying or unsatisfying event by contacting with other consumers purchasing the houses in the same estate through electric ways(network, mobile phone, and other electronic equipments) during the investigation period before purchasing the house, selection-making and signing purchase contract period in the house-purchasing process, the waiting period after purchasing the house, and the occupancy period after house purchasing. The event was required to be indicated in detail, including time, contact mode and environment, other customer's words and deeds, and the feel. The research activities continued for 4 weeks. A total of 210 questionnaires were recovered and 109 effective questionnaires was obtained finally, namely, 109 effective events.

Three teachers, including the authors of this study, took charge of classifying the key events. The preliminary classification framework was established in reference with the researches concerning ECCI in existing researches. The reliability index proposed by Perreauh \& Leigh (1989) was used to check the reliability of the classification results,

$$
I_{r}=\sqrt{\frac{\left(\frac{F_{0}}{N}-\frac{1}{K}\right)}{\left(\frac{K}{K-1}\right)}}
$$

Where, $I_{r}$ is reliability index, $F_{0}$ is the number of the event having mutual consent, $N$ is the total number of samples, $K$ is the number of classes.

In this study, 102 key event yields consistent classification results from the first and second researchers, that is, $\mathrm{F} 0=102, \mathrm{~N}=109$, and $\mathrm{K}=6$. By calculation, reliability index $\mathrm{Ir}$ is 0.8 , which is acceptable. Therefore the judgment results of the former two researchers have higher reliability. Next, using the same method, 104 key events show consistent classification results from the second and third researcher, that is, F0 $=102$ and reliability index $\mathrm{Ir}=0.81$, which is higher than 0.8. Therefore, this classification is highly reliable.

\subsection{The results of exploratory study and discussion}

The classification on 109 questionnaires using critical incident method suggested that the ECCI mainly includes three types, namely, advice and help, friendly conversation, and negative information and bad attitude.

(1) Advice and help: This class majorly refers to that customers share purchasing and living experiences or provide help. A total of 38 cases are involved in. These ECCI behaviors generally happen in the period before house purchasing and the period after occupancy. In different periods, different contents are concerned. Therefore, according to period, this class is further divided into two subclasses, namely, pre-occupancy and postoccupancy. The first sub-class refers to the advice and help provided by other customers for house purchasing. It accounts for $48 \%$ of all advice and help cases. The second class represents the advice and help offered by other customers after occupancy and takes a proportion of $52 \%$

(2) Friendly conversation: the ECCI of this class expands the social network of customers and contains a total of 32 cases. These ECCI behaviors can be divided into two categories according to content: the first category refers to the friendly attitude in the conversation and accounts for $40 \%$ of the friendly conversation cases; the second category denotes to provide friendly information in customer's conversation and takes a proportion of $60 \%$ of the friendly conversation cases.

(3) Negative information and bad attitude: This ECCI class reduces the satisfaction level of customer on purchasing and living and includes a total of 39 cases. The negative information is a class and accounts for $41 \%$, while bad attitude is another type and accounts for $59 \%$.

\section{EMPIRICAL STUDY ON ECCI}

\subsection{Measurement scale setting and presurvey}

According to exploratory research results, the dimension of the ECCI in real estate consumption is 
constituted by three study variables, including advise and help, and friendly conversation and bad attitude. This study used the literature review and in-depth interview to determine the measurement terms of the variables. A total of 23 initial measurement terms were obtained. Using the Likert5-level scale, 1 represents few occurrence times while 5 suggests a lot occurrence times.

Two hundred customers bearing housepurchasing experiences were randomly selected for presurvey. One hundred and twenty questionnaires were recovered, including 98 effective questionnaires. The effective questionnaires were then conducted with data process. Reliable analysis was used firstly to test the reliability of the questionnaire. Two terms with corrected item total correlation (CITC) below 0.5 were eliminated. Then the residue 21 terms were operated with factor analysis using SPSS19.0. The results suggested benign structural reliability. Therefore, formal questionnaire included 21terms, as shown in Table1.

Table 1 The formal measurement scale for ECCI

\begin{tabular}{|c|c|c|}
\hline $\begin{array}{l}\text { Structural } \\
\text { dimension }\end{array}$ & No. & Measurement terms \\
\hline \multirow{8}{*}{$\begin{array}{l}\text { Advice and } \\
\text { help }\end{array}$} & ec1 & Some customers are pleased to share the house-purchasing experiences \\
\hline & ec2 & Some customers provide reasonable suggestions in the selection process of house-purchasing \\
\hline & ec3 & Some customers provide advice on purchasing way so that other customers obtain more preference \\
\hline & ec4 & Some customers share the shopping experience around the community \\
\hline & ec5 & Some customers prompt to pay attention the safety of the community \\
\hline & ec6 & Some customers recommends to care the public environment in the community \\
\hline & ec7 & Some customers provide second-hand transactions so that others can be benefited \\
\hline & ec8 & Some customers share complaints experience and obtain the approval of others customers \\
\hline \multirow{8}{*}{$\begin{array}{c}\text { Friendly } \\
\text { conversation }\end{array}$} & ec9 & The friendly attitude in the interaction makes me feel cheerful \\
\hline & ec10 & Many common topics are found in the interaction and valuable information are obtained \\
\hline & ec11 & The new friends made in the interaction increase the approval sense for living there. \\
\hline & ec12 & The active purchasing attitude of some customers strengthened my purchasing decision \\
\hline & ec13 & I want to participate in the other customers' community actives known by interaction \\
\hline & ec14 & Sharing information in the interaction make my house-purchasing process to be more simple and easy \\
\hline & ec15 & It is anxious and happy to share the community actives in the interaction \\
\hline & ec16 & Interaction acts part of my social communication \\
\hline \multirow{5}{*}{$\begin{array}{c}\text { negative } \\
\text { information } \\
\text { and bad } \\
\text { attitude }\end{array}$} & ec17 & Some customers complain about the product or enterprise while do not solve the problems \\
\hline & ec18 & Some customers let off unhealthy emotions and influence the feeling of others \\
\hline & ec19 & Some customers use uncivilized words and disregard etiquette \\
\hline & ec20 & Some customers come into conflict and do not solve the conflict using positive measures \\
\hline & ec21 & Some customers provide unreal or unclear information \\
\hline
\end{tabular}

\subsection{Formal survey and results analysis}

Formal large-scale survey used a way of issuing questionnaire through network. Three hundred customers were selected as the investigation objects. In this empirical study, a total of 400 questionnaires were distributed and 280 questionnaires were recovered, including 201 effective questionnaires. Firstly, the formal measurement scale was conducted with reliability test using SPSS19.0. Table 2 shows the reliability analysis results. The CITC of terms in the scale on corresponding dimension all exceeded 0.5 of the lowest standard and Cronbach $\alpha$ on each dimension all surpassed the acceptable levels. The scale showed benign internal consistency reliability.

Subsequently, confirmatory factor analysis was used for proving reliability. Table 2 shows the test results of the confirmatory factor analysis model using AMOS17.0. The standardized factor load of the factor corresponded to each variable lay in $0.735 \sim 0.918$, which was in the range of $0.5 \sim 0.95$; load factor was significant at level of $P<0.001$ level and all passed through the $t$ test. Therefore, the hypothesized relationship of the 3 factors with 21 items is objectively available. As for each fitting indexes, $\chi 2=237.117 ; \chi 2 / \mathrm{df}=1.275$. the two values all smaller than 3; normed fit index $(\mathrm{NFI})=0.952$, comparative fit index $(\mathrm{CFI})=0.989$, and tall latte index $(\mathrm{TLI})=0.988$. The three indexes all exceed 0.9 ; parsimony goodness of fit index $(\mathrm{PGFI})=0.725$ and parsimony normed fit index $(\mathrm{PNFI})=0.842$. The two values all exceed 0.5 ; root mean square error of approximation $(\mathrm{RMSEA})=0.037$, which is lower than 0.8 . The estimated value of primary parameters all reach to the significant level on statistics, suggesting the high fit degree of model and data. Meanwhile, the average value (AVE) of the three potential variables calculated by composite reliability equation all exceed 0.5 . This suggests the 
benign convergent validity of the measurement terms at different dimensions in the scale and the favorable internal quality of the model. Therefore, this measurement model shows ideal fitting degree.

Table 2 The reliability test results and confirmatory factor analysis results of the electronic customer-to-customer structural model

\begin{tabular}{|c|c|c|c|c|c|c|c|c|c|}
\hline Factors & No. & CITC & $\begin{array}{l}\text { Cronbach } \alpha \text { if } \\
\text { Item Delected }\end{array}$ & Cronbach $\alpha$ & $\begin{array}{c}\text { Estimate } \\
\text { (UnStandardized) }\end{array}$ & AVE & $\begin{array}{c}\text { Estimate } \\
\text { (Standardized) }\end{array}$ & $\mathrm{T}$ & $\mathrm{P}^{*}$ \\
\hline \multirow{8}{*}{$\begin{array}{l}\text { Advice and } \\
\text { help }\end{array}$} & ec1 & 0.835 & 0.793 & \multirow{8}{*}{0.958} & 1.000 & \multirow{8}{*}{0.958} & 0.853 & & \\
\hline & ec2 & 0.806 & 0.793 & & 1.064 & & 0.855 & 16.178 & $* * *$ \\
\hline & ec3 & 0.792 & 0.795 & & 0.985 & & 0.817 & 14.914 & $* * *$ \\
\hline & ec4 & 0.863 & 0.791 & & 1.104 & & 0.906 & 18.079 & $* * *$ \\
\hline & ec5 & 0.778 & 0.796 & & 1.005 & & 0.846 & 15.850 & $* * *$ \\
\hline & ec6 & 0.860 & 0.792 & & 1.032 & & 0.882 & 17.137 & $* * *$ \\
\hline & ec7 & 0.831 & 0.792 & & 1.078 & & 0.880 & 17.065 & $* * *$ \\
\hline & ec8 & 0.802 & 0.796 & & 0.967 & & 0.851 & 16.033 & $* * *$ \\
\hline \multirow{8}{*}{$\begin{array}{c}\text { Friendly } \\
\text { conversation }\end{array}$} & ec9 & 0.819 & 0.798 & \multirow{8}{*}{0.953} & 1.000 & \multirow{8}{*}{0.961} & 0.871 & & \\
\hline & ec10 & 0.780 & 0.801 & & 0.914 & & 0.835 & 16.077 & $* * *$ \\
\hline & ec11 & 0.818 & 0.798 & & 1.006 & & 0.858 & 16.961 & $* * *$ \\
\hline & ec12 & 0.820 & 0.799 & & 0.987 & & 0.880 & 17.864 & $* * *$ \\
\hline & ec13 & 0.802 & 0.799 & & 1.000 & & 0.875 & 17.640 & $* * *$ \\
\hline & ec14 & 0.820 & 0.797 & & 1.060 & & 0.875 & 17.672 & $* * *$ \\
\hline & ec15 & 0.833 & 0.797 & & 1.066 & & 0.890 & 18.296 & $* * *$ \\
\hline & ec16 & 0.777 & 0.799 & & 1.013 & & 0.866 & 17.278 & $* * *$ \\
\hline \multirow{5}{*}{$\begin{array}{c}\text { Negative } \\
\text { information } \\
\text { and bad } \\
\text { attitude }\end{array}$} & ec17 & 0.779 & 0.872 & \multirow{5}{*}{0.896} & 1.000 & \multirow{5}{*}{0.899} & 0.778 & & \\
\hline & ec18 & 0.792 & 0.864 & & 0.847 & & 0.799 & 12.870 & $* * *$ \\
\hline & ec19 & 0.729 & 0.860 & & 0.746 & & 0.735 & 11.580 & $* * *$ \\
\hline & ec20 & 0.757 & 0.860 & & 0.769 & & 0.764 & 12.159 & $* * *$ \\
\hline & ec21 & 0.912 & \begin{tabular}{|l|}
0.876 \\
\end{tabular} & & \begin{tabular}{|l|}
1.159 \\
\end{tabular} & & \begin{tabular}{|l|}
0.918 \\
\end{tabular} & 15.504 & $* * *$ \\
\hline Model Fit & \multicolumn{9}{|c|}{$\chi^{2}=237.117, \chi^{2} / d f=1.275, N F I=0.952, C F I=0.989, T L I=0.988, P G F I=0.725, P N F I=0.842, R M S E A=0.037$} \\
\hline
\end{tabular}

$* \mathrm{P}$ is ***, suggesting $\mathrm{P}<0.001$

\section{CONCLUSION}

This research carries out an exploratory research on ECCI behavior in real estate consumption using the critical incident method and determined the three primary categories in real estate consumption. On this basis, combining with existing relative literature and in-depth interview, it developed the ECCI measurement scale and verified the scale through empirical study. The analysis results suggested that CCI in virtual environment affected customer's consumption in real environment. Enterprises should pay attention to the changes brought by technology to enterprises and customers, and explore channels to strengthen the relationship between customer and enterprises. In addition, it needs to create more positives events of ECCI and reduce the negative events of ECCI.

\section{REFERENCES}

[1] Baron, S. \& Harris, K. 2007. Interactions and relationship from the consumer experience perspective. Proceedings of the QUIS 10 Conference. FL: Orlando.
[2] Clark, T.\& Martin, C. 1994. Customer-to-customer: the forgotten relationship in relationship marketing. Proceedings of the First Research Conference on Relationship Marketing, Atlanta, GA.

[3] Dominik Georgi, \& MoritzMink. 2013. eCCIq: The quality of electronic customer-to-customer interaction. Journal of Retailing and Consumer Services 20(2):11-19.

[4] Jiang Ting. 2012. The influences of customer-to-customer interaction on the repatronage intention -a case study of group traveler. Doctoral Dissertation of Shandong University 5:25-50. Ji'nan: China.

[5] Libai, B. 2010. Customer-to-customer interactions: Broadening the scope of word of mouth research. Journal of service research 13(3): 267-282.

[6] Martin, CI. 1996. Consumer-to-consumer relationships: satisfaction with other consumers' public behavior. Journal of Consumer Affairs 2(30): 146-69.

[7] Muniz, A. 2001. Communities. Journal of Consumer Research 27(4): 412-432.

[8] Nicholls, R. 2008. Customer-to-customer interaction in the world of e-service. Service Management 3(2): 97-104.

[9] Nicholls, R. 2010. New directions for customer-tocustomer interaction research. Journal of Services Marketing 24(1): 87-97.

[10] Perreauh, W.D. \& Leigh, L.E. 1989. Reliability of nominal data based on qualitative judgments. Journal of Marketing Research 26(2): 135-148. 